\title{
MICRONUTRIENT CONTENT OF BREAST MILK
}

Sunita Koreti ${ }^{1}$, Nitin Prasad $^{2}$

\section{HOW TO CITE THIS ARTICLE:}

Sunita Koreti, Nitin Prasad, "Micronutrient Content of Breast Milk". Journal of Evolution of Medical and Dental Sciences 2014; Vol. 3, Issue 07, February 17; Page: 1633-1638, DOI: 10.14260/jemds/2014/2036

ABSTRACT: Considering that in exclusively breast-fed infants, breast milk is the sole source of the nutrition for the first few months of life, it is important to have accurate data on its composition. Various studies have been done on factors affecting the concentration of microelements in breast milk. Through this article we tried to address the iron, zinc, copper content of breast milk which is most essential micronutrients for growth of infant. A wide range of values for iron in the breast milk (0.1- $1.6 \mathrm{mg} / \mathrm{l}), \mathrm{Zn}$ and $\mathrm{Cu}$ were 625 (475-889) microgram/l and 239 (200-296) microgram/l respectively have been reported in the literature in all stages of lactation. Concentration of micronutrients is high in colostrum and decreases during the lactation period. Maternal serum levels of microelements have no correlation with those in breast milk. Various studies have shown mineral, multivitamin, supplementation or maternal diet does not affect breast milk micronutrient concentration. Mother's age, parity, anthropometry, smoking habits, socioeconomic status, residing area(rural/urban), environment, use of oral contraceptive do not have an influence on the micronutrient content of the mother's milk.

KEYWORDS: Breast milk, Micronutrient, Iron, Zinc, Copper.

INTRODUCTION: Human milk is considered to be the optimal source of nutrition for the infant 1 . Breast milk from a lactating mother is nutritionally superior to formulas and can provide the newborn with adequate nutrition and bioactive components for the first 6 months of life. Thus, W.H.O and American Academy of Pediatrics recommends exclusive breast feeding for the first 6 months after birth and continued breast feeding along with complementary foods for 24 months or longer. ${ }^{1}$ For exclusive breast-fed infants, milk must be nutritionally adequate, and provide the trace elements needed for normal growth and development Although trace minerals concentration is relatively low in human milk and blood, they play a critical role in many physiological processes. ${ }^{2}$ Copper $(\mathrm{Cu})$ body stores are sufficient at birth to protect infant from deficiency until 4-6 month, but zinc (Zn) body storages are not extensive, and it should be taken in adequate quantity for optimal growth and development. ${ }^{3}$ Each trace element Iron, $\mathrm{Zn}, \mathrm{Cu}$ exhibits certain functions and have critical roles for infant growth. ${ }^{4,5}$

Public Health concern: Micronutrient deficiency is widely prevalent in India and other developing countries. Iron, zinc deficiency is very common among mother as well as children. Iron (Fe), and zinc deficiency are public concern during infancy and in mother. Prevalence of iron deficiency anemia among pregnant women is 59\% and 63\% among breastfeeding mothers. Thus the prevalence is more in breast feeding mothers than pregnant women with the burden of disease disturbing both mother and new born and subsequent child. Iron deficiency in early life may have long-term adverse effects on cognitive development.6,7 While breastfeeding is nearly universal in India, very few children are put to the breast immediately after birth. Only one-quarter of last-born children who were ever breastfed, started breastfeeding within half an hour of birth as per recommendation, and almost half 
(45 percent) did not start breastfeeding within one day of birth. Most mothers (57 percent) give their child something to drink other than breast milk in the three days after delivery. Only 69 percent of children under two months of age were exclusively breastfed. Exclusive breastfeeding drops to 51 percent at 2-3 months of age and 28 percent at 4-5 months of age. Overall, slightly less than half of children under six months of age are exclusively breastfed (National Family Health Survey India- 3, 2005-2006). The Millennium Developmental Goal (MDG) also included the improvement in maternal health and reduction in child mortality. These two goals can be achieved with improvement of nutritional status of both mother and infant. Infants are dependent only on milk for first 6 month, as breast milk is superior to any other milk or formula feed; exclusive breast feeding is recommended for first 6 month and continues till 2 years of life or more with complimentary diet by W.H.O. and UNICEF.

BREAST MILK IRON, ZN, and CU PHYSIOLOGY: Picciano et al $^{1}$ reported that the iron content of the mother's milk utilized extremely well, the absorption mechanism has not been clarified yet in every aspect, however. Mother's milk iron is utilized five times better than from cow's milk due to iron binding lactoferrin. According to Cumming et al ${ }^{8}$; Fransson and Lonnerdal9, 10 Hirai et al ${ }^{11}$ the iron is bounded mainly to the low molecular weight peptides (18-56\%), the fat micelles (15-46\%) and the lactoferrin (16-40\%). Concentration of the main metal transporting proteins decreases with the advance of the lactation, but with the decrease of the lactoferrin the iron concentration of the milk does not change. Lonnerdal et al $^{12}$ have investigated the potential correlation between hemoglobin or iron stores (ferritin) and milk iron, it is more likely that iron taken up by the mammary gland is supplied by circulating iron, i.e., serum iron. Similarly the higher bioavailability of zinc and copper is explained by milk protein composition. Thus human milk proteins primarily lactoalbumin are readily digestible in contrast to casein which is the major component of cow's milk, so that bound zinc is more available for absorption. ${ }^{13}$

BREAST MILK IRON, ZINC, and COPPER ESTIMATION: To determine micronutrient content of breast milk, various methods are available, however the most convenient and simple method today is microwave digestion of the milk, followed by atomic absorption spectrometer. M.D. Silvestre et al ${ }^{14}$ conduct the study for determining copper, iron and zinc in human milk .It includes microwave mineralization of the sample and measuring the elements by Flame atomic absorption spectroscopy (FAAS). Only $2 \mathrm{ml}$ of milk is needed, and the method is free of matrix interferences. The values obtained for the detection limits $(0.07 ; 0.07 ; 0.11 \mathrm{mg} / \mathrm{ml} \mathrm{milk,} \mathrm{for} \mathrm{copper,} \mathrm{iron} \mathrm{and} \mathrm{zinc)} \mathrm{precision} \mathrm{of}$ the method, intra-assay (2.9; 5.2; 6.1\%RSD for copper, iron and zinc) and accuracy, evaluated using recovery assays (98.8; 100.4; $95.9 \%$ for copper, iron and zinc) show that the method is useful for the purpose mentioned. Moreover, the method is rapid and simple.

IRON, COPPER, ZINC CONTENT IN BREAST MILK: A wide range of values for iron in the breast milk (0.1- $1.6 \mathrm{mg} / \mathrm{l}$ ) have been reported in the literature at all stages of lactation (Khurana et al 15 , Picciano and Guthrie ${ }^{16}$ Murray et al. ${ }^{17}$, Celada et al. ${ }^{18}$ ), quoted a mean value of $1.0 \mathrm{mg} / \mathrm{l}$ for the iron content in colostrum and iron concentration ranging $0.20-0.80 \mathrm{mg} / \mathrm{l}$ for the mature breast milk (15 days-15 months postpartum). Iron content of human milk is highest in early transitional milk $(0.97 \mathrm{mg} / \mathrm{l})$ Lauber and Reinhardt. ${ }^{19}$ In study done by Emel, S Songiil Yalcin et al the median concentration of $\mathrm{Zn}$ 
and $\mathrm{Cu}$ were 625(475-889) microgram/L and 239(200-296) microgram/L respectively ${ }^{20}$ The values reported in different studies may be due to differences in sampling procedures as well as stage of lactation. The analysis method, sampling time (foremilk-hind milk or morning-afternoon-night), sampling methods (pump, manual suckling), stages of lactations, inter-individual variability might be possible reason for different result in various studies ${ }^{21,22}$

CONCENTRATIONS OF IRON, ZINC, COPPER IN COLOSTRUM: Concentration of micronutrients are high in colostrum and decreases during the lactation period ${ }^{23-26}$ The initial mean value of iron was $0.56 \mathrm{mg} / \mathrm{L}$ in colostrum to $0.39 \mathrm{mg} / \mathrm{L}$ at day30 postpartum, remaining stable until the end of the study conducted by M.D. Silvestre et al ${ }^{23}$. Similarly concentration of zinc and copper is high in colostrum, zinc was found to be $5.32 \mathrm{microgram} / \mathrm{ml}$ in colostrum to $1.12 \mathrm{microgram} / \mathrm{ml}$ at $7 \mathrm{month}$, and copper level fell from $0.46 \mathrm{microgram} / \mathrm{ml}$ in colostrum to 0.17 microgram $/ \mathrm{ml}$ at 7 month in study done by Rajlakshmi K, Shrikantia SG ${ }^{26}$

FACTORS AFFECTING THE MICRONUTRIENT CONCENTRATION: Considering that in exclusively breast-fed infants, breast milk is the sole source of the nutrition for the first few months of life, it is important to have accurate data on its composition. Various studies have been done on factors affecting the concentration of microelements in breast milk.

1. STAGE OF LACTION: Various studies conducted to determine the factors that affect milk iron, zinc and copper content at the different stages of lactation. Milk micronutrient content declines significantly from the second week to the four to seven month postpartum ${ }^{23-28}$

2. SERUM LEVELOF MICROELEMENTS: Concentration of microelements in serum was not correlated with those in breast milk shown in various studies. Iron deficiency and iron deficiency anemia are very common worldwide, and the potential effect of low maternal iron status on breast milk iron concentration has been explored in lactating women. Maternal iron status assessed by hemoglobin, serum ferritin, and transferrin saturation was found not to be correlated with milk iron in a study of Swiss women by Celeda et al ${ }^{17}$.Similar observations were made in a group of Nigerian women with considerably more variable iron status. (Murray et al ${ }^{18}$ ). In contrast with these studies, a study in India suggested a positive effect of maternal iron deficiency on milk iron (Fransson et al ${ }^{29}$ ) Severely anemic women $(\mathrm{Hb}<80 \mathrm{~g} / \mathrm{L})$ had significantly higher milk iron concentrations than nonanemic women $(\mathrm{Hb}>110 \mathrm{~g} / \mathrm{L})$. Concentrations of lactoferrin, the major iron-binding protein in human milk, were also higher in the anemic women.

Domelloff et al. ${ }^{30}$ examined the iron, zinc and copper content of milk of 191 Swedish and Honduran mothers, as well as the relationship between the mineral status of the mother. It was concluded that the iron, zinc, copper content of the milk was not affected by mother's serum level of micronutrient during the period of nine months after the child- birth.

3. EFFECT OF SUPPLIMENTATION AND DIET: Daily, weekly, and within-day variations in iron content of human milk were investigated by, Reza Mahdavi et al. ${ }^{31}$ No differences were found in milk of women receiving dietary mineral and vitamin supplements, or with different diet. In various other 
studies has shown mineral, multivitamin supplementation or maternal diet does not affect breast milk zinc, copper concentration 20,26,31,32

4. MATERNAL FACTOR: Iron, zinc, copper are essential micronutrients for Growth and development. The maternal factors are very important factors that can influence the micronutrient content of breast milk. Various studied variations include maternal stature, age, residing area, family income, length of gestation, gravida, smoking, traditions and literacy, oral contraceptives etc. Kirksey et al ${ }^{33}$ Jose G. Dorea et $\mathrm{al}^{34}$ conducted a study to determine the effects of oral contraceptive (OC) treatment on maternal iron metabolism during lactation. Results show the use of Oral Contraceptives does not appear to affect significantly the secretion of iron in breast milk during the first months of lactation. Established that the contraceptives did not have an influence on the iron content of the milk in the long run, Mother's age, parity, anthropometry, smoking habits, socioeconomic status, literacy residing area(rural/urban), environment do not have any influence on the micronutrient iron, zinc, copper content of the mother's milk ${ }^{15,20,22,23,25,26,32}$

CONCLUSION: Colostrum is rich in microelements iron, zinc, copper, which are essential for growth of infants. That supports the feeding protocol of initiation of breastfeeding within 30 minutes of birth, recommended by W.H.O and UNICEF also known as golden hour.

Micronutrient content of breast milk is not affected by any maternal factors anthropometry, socioeconomic status, food habits, supplementation, age, parity, nutritional status (deficiency), residing area, and use of oral contraceptives. Irrespective of any maternal, environmental, social factors breast feeding should be recommended. Breast milk is superior to all optional neonatal feeding.

\section{REFERENCES:}

1. WHO (2001) Optimal duration of exclusive breast feeding, WHO A54/INF Doc/4, 1.

2. Mary Frances Picciano. Nutrient Composition of Human Milk: Pediatric Clinics of North America: Volume 48, Issue 1, February 2001.

3. World Health Organization (WHO). Report of a joint WHO/IAEA Collaborative Study, Minor and Trace Element in Breast milk. World Health Organization, Geneva, 1989.

4. Prasad AS. Impact of discovery of human zinc deficiency on health: J Am Coll Nutr.2009; 28: 257-65.

5. Turski ML, Thiele DJ. New role for copper metabolism in cell proliferation, signalling and disease. J Biol Chem.2009; 284: 717-21.

6. Lozoff B, Wolf AW, Jimenez E. Iron deficiency anaemia and infant development: effects of extended oral iron therapy: J Pediatric, 1996; 129(3):382-389.

7. Lozoff B, Jimenez E, Hagen J, Mollen E, Wolf AW. Poorer behavioural and developmental outcome more than 10 years after treatment for iron deficiency in infancy. J Pediatrics 2000; 105(4):51.

8. F. J. Cumming, J.J. Fardy, M.H. Briggs. Trace elements in human milk. Obstetet Gynecol, 62 (4)(1983) 506-508.

9. G.B. Fransson, B. Lonnerdal. Iron in human milk. Journal of Pediatrics, 96 (1980) 380-384. 
10. G. B. Fransson, B. L"onnerdal. Iron, copper, zinc, calcium, and magnesium in human milk fat. American Journal of Clinical Nutrition, 39 (1984) 185-189 p.

11. Y. Hirai, N. Kawakata, K. Satoh, Y. Ikeda, S. Hisayasu et al. Concentrations of lactoferrin and iron in human milk at different stages of lactation. Journal of Nutritional Science and Vitaminology, 36 (1990) 531-544.

12. Lönnerdal B. Regulation of mineral and trace elements in human milk: exogenous and endogenous factors. Nutr Rev 2000; 58: 223-9.

13. A. Frkovik, B Medgoracb, A Alebi et al. Zinc level in human milk and umbilical cord blood: The Science of total environment:192(1996)207-212

14. M.D Silvestre et al. Copper, iron and zinc determinations in human milk using FAAS with microwave digestion: Food Chemistry 68 (2000) 95-99.

15. Khurana V, Agarwal KN, Gupta S. Iron content of breast milk. Indian Pediatric 7(1970), 659661.

16. Picciano MF, Guthrie HA. Copper, iron and zinc contents of mature human milk. Am J Clin Nutr $1976 ; 29,242-254$.

17. Murray MJ, Murray AB, Murray NJ, Murray MB. The effect of iron status of Nigerian mothers on that of their infants at birth and 6 months, and on the concentration of Fe in breast milk. Br J Nutr 1978; 39, 627-630.

18. Celada A, Brusset R, Gutierrez J, Herreros V. No correlation between iron concentration in breast milk and maternal iron stores. Helv Paediatr Acta 1982; 37: 11-6.

19. Lauber E, Reinhardt M. Studies on the quality of breast milk during 23 months of lactation in a rural community of the Ivory Coast. Am J Clin Nutr 1979; 32, 1159-1173.

20. Emel Orun, S Songul Yalcin et al. Zinc and copper concentration in breast milk at the second month of lactation. Indian Pediatric 2012; 49: 133-135

21. Neville MC, Keller RP, Secat J et al. Studies on human lactation, within feed and between breast variations in selected components of human milk. Am J Clin Nutr, 1984: 40: 635-46

22. Silver MD, Lagarda M J, Farre R, Martinez - Costa C et al. Study of factors that may influence the determination of copper, iron and zinc in human milk during sampling and in sample individuals. Biol Trace Elem Res.200:76:217-27.

23. M.D. Silvestre, M.J. Lagarda, R. Farre Â et al. Copper, iron and zinc determinations in human milk using FAAS with microwave digestion. Food Chemistry 68(1), 2000: 95-99.

24. Ruth M Feeley, Ronald R Eitenmiller, L Benton Jones et al. Copper, iron and zinc contents of human milk at early stages of lactation. The American journal of clinical nutrition, 37(1983):443-448

25. J. Arnaud, A. Favier. Copper, iron, manganese and zinc contents in human colostrum's and transitory milk of French women. The Science of the Total Environment, 159 (1995) 9-15.

26. Rajalaksmi K, Srikantia SG. Copper, zinc and magnesium content of breast milk on Indian women. Am J Clin Nutr: 1980Mar: 33(3): 664-9

27. Siddika Songul Yalcın, Ali Baykan, Kadriye Yurdako"k, Suzan Yalc et al. The Factors That Affect Milk-to-Serum Ratio for Iron During Early Lactation J Pediatric Hematol Oncol _ Volume 31, Number 2, February 2009.

28. Jose Dorea. Zinc and copper concentration in breast milk. Indian paediatrics: 49: 2012: 592 
29. Fransson GB, Agarwal KN, Gebre-Medhin M, Hambraeus L. Increased breast milk iron in severe maternal anaemia: physiological "trapping" or leakage? Acta Paediatr Scand 1985; 74: 290-1

30. Domello f M, Lonnerdal B, Dewey KG, Cohen RJ, Hernell O. Iron, zinc, and copper concentrations in breast milk are independent of maternal mineral status. Am J Clin Nutr. 2004; 79(1): 111115.

31. Reza Mahdavi, Leila Nikniaz and Seyed Jamal Gayemmagami et al. Maternal body mass index, dietary intake, and socioeconomic status: Differential effects on Breast milk zinc, copper, and iron content. Health Promotion Perspectives. vol 1, No 2, 2011:p:140-146.

32. Phylis B Moser and Robert D Reynolds. Dietary zinc intake and zinc concentrations of plasma, erythrocytes, and breast milk in ante partum and postpartum lactating and non-lactating women: AJC Nutr 1983; 38: 10l-108.

33. A. Kirksey, J.A. Ernst, J.L. Roepke, T.L. Tsai. Influence of mineral intake and use of oral contraceptives before pregnancy on the mineral content of human colostrum and of more mature milk, American Journal of Clinical Nutrition, 32 (1979) 30-39.

34. J.G. Dorea, E.S. Miazaki. The effects of oral contraceptive use on iron and copper concentrations in breast milk, Fertility and Sterility, 72, 2 (1999) 297-301.39.

\section{AUTHORS:}

1. Sunita Koreti

2. Nitin Prasad

\section{PARTICULARS OF CONTRIBUTORS:}

1. Associate Professor, Department of Paediatrics, G.R. Medical College, Gwalior, M.P, India.

2. Demonstrator, Department of Forensic Medicine, S.S. Medical College, Rewa, M.P, India.

\section{NAME ADDRESS EMAIL ID OF THE CORRESPONDING AUTHOR:}

Dr. Sunita Koreti, S-14A, Sarika Nagar, Darpan Colony, Thatipur, Gwalior, M.P, India.

E-mail: drsunitaprasad@yahoo.in

Date of Submission: 17/01/2014. Date of Peer Review: 18/01/2014. Date of Acceptance: 01/02/2014. Date of Publishing: 12/02/2014. 